Article

\title{
Reducing the Carbon Footprint of the Bucharest University of Economic Studies through Green Facades in an Economically Efficient Manner
}

\author{
Simona Roxana Pătărlăgeanu ${ }^{1}$, Costel Negrei ${ }^{1}$, Mihai Dinu ${ }^{1, *}$ and Roxana Chiocaru ${ }^{2}$ \\ 1 The Faculty of Agrifood and Environmental Economics, The Department of Agrifood and Environmental \\ Economics, Bucharest University of Economic Studies, 5-7 Mihail Moxa Street, District 1, 010961 Bucharest, \\ Romania; rpatarlageanu@eam.ase.ro (S.R.P.); costel.negrei@eam.ase.ro (C.N.) \\ 2 The Faculty of Biology, The Department of Systems Ecology and Sustainability, University of Bucharest, \\ Splaiul Independenței Street, 91-95, 050095 Bucharest, Romania; chiocaruroxana@gmail.com \\ * Correspondence: mihai.dinu@eam.ase.ro
}

Received: 7 March 2020; Accepted: 29 April 2020; Published: 6 May 2020

check for updates

\begin{abstract}
This paper focuses on the current environmental issues, more specifically the amount of greenhouse gases humanity is being confronted with at the moment. The research was carried out on a niche of the topic, namely on the carbon footprint of public buildings. The concept of a sustainable university is new and insufficiently explored, and as part of the environmental metabolism, it influences anthropic sustainability in a directly proportional manner. This indicator's monitoring systems reveal how vulnerable humanity is in front of the latency of an unprecedented and inevitable environmental catastrophe. The ecological effects may be mitigated by the academic community through green urban design. The ecological performance can be expressed in an economically efficient manner, which can, at the same time, create a precious channel of communication within the entire academic community though volunteering for sustainability. Moreover, this research has identified several solutions for optimizing the carbon footprint, which do not hinder the necessary economic development. Within the current context, when most economic activities are leading to ecological collapse, sustainability should be reprioritized with the help of the academic society, through the examples offered by applied research. The premises of this research were represented by bibliometric analyses and the results obtained have proven its importance, as well as the importance of certain scenarios involving solutions for improving the metabolism of nature.
\end{abstract}

Keywords: sustainability; sustainable university; ecological collapse; climate change; green vertical facades

\section{Introduction}

Environmental, social and ethical incidents are currently occurring more and more frequently worldwide, generating environmental costs and repercussions that are difficult to correct in the short and medium term. Up until now, academic research focusing on reducing the carbon footprint has not had a significant impact due to the lack of communication between society and the academic environment. This research study intends, on the one hand, to propose economically efficient solutions for improving the way in which academic institutions communicate their findings related to the reduction of the carbon footprint, and on the other hand, to involve the whole academic community in a dialogue with society at large. At the international level, applying the solutions proposed by this research can generate a sustainable micro environment in any academic unit.

Romania has been chosen for this case study because its living standard is considered to be one of the lowest within the European Union and because it is in dire need of improving various 
environmental-related aspects, in spite of having been the first Eastern European country to sign the Renewable Energy and Energy Efficiency Partnership.

The carbon footprint, which represents the most influential component of the ecological footprint [1], is the indicator that should be optimized in the short term in order to impact climate change in a positive manner. The metabolism of the environment is closely connected to the carbon footprint, which, in its turn, is influenced by the quantity of carbon released into the air, as part of the greenhouse gases. This indicator, which has recently started to be monitored, comes as a response to the people's need to perform their activity in a safe and sustainable environment, beneficial for both the current generation and the ones to come.

The objective of this paper is to prove that when trying to reach a global objective, small actions can have a strong impact due to their capacity to repair the erroneous approaches adopted in comfortable times. One of the main causes that carbon is released into the air we breathe is related to the instinctual or irresponsible type of consumption and this is true overall, not only when referring to Romania.

The economic efficiency model of sustainability, specifically the reduction of the carbon footprint, can be communicated through the empirical method of the example, by, which the academic communities demonstrate the applicability and efficiency of a lifestyle guided by the principles of sustainability.

During the first world conference on air pollution, which took place in Geneva in 2019, various statements were formulated about how people's health is affected by this type of pollution. The conference was jointly organized by the United Nations, the World Bank and the European Commission, and representatives of these institutions presented initiatives that gave humanity a series of objectives to reach by 2030, the main focus being that of having nearly zero carbon emissions.

At this moment, air pollution in households represents an important cause for why an increasing number of people are developing illnesses, such as various types of pneumonia or other infections of the lower respiratory tract, which is an indication for researchers that concrete solutions are necessary in order to meet the needs of the modern world.

In terms of deaths caused by air pollution, it has been proven that the emissions produced by industrial activity, cars and trucks have a higher impact on people than the air pollution in households.

Since the international and domestic legal framework oblige all the levels of society, public and private alike, to rationalize the use of resources (especially fossil fuels) and to reduce the current carbon levels, this is no longer a mere indication to change the approach used so far, but an emergency.

The first part of this paper offers an overview of the theoretical approaches of the past 50 years from three points of view - the historical perspective, the correlation with globalization and the importance of the carbon footprint of public buildings. Although these are not dwelling places, people spend around $8 \mathrm{~h}$ per day on average there.

The cost-benefit analysis for green buildings will then be compared and contrasted with the environmental cost-benefit analysis. This aspect was studied because the publications on this topic have been insufficiently turned to account in Romania, the present paper indicating a desire to evolve, to be proactive and to apply the proposed actions.

Green vertical facades are not new in the world, but it is a fact that they can ensure protection to a building, reduce its carbon footprint and bring many other benefits in a limited urban space. The trend of green vertical facades was popular in North America and Western Europe at the beginning of the $19^{\text {th }}$ century, but the sun or acid rains destroy them over time, so due to the fact that their maintenance was not economically efficient at that moment the trend became unpopular [2] (pp. 423-236).

The academic literature mentions that noise pollution, urban heat pollution and air pollution can be mitigated through green facades, which can, moreover, bring energy-saving benefits [3-6].

Further on, the paper refers to public buildings. Two of the buildings in the complex of the Bucharest University of Economic Studies (henceforth referred to as BUES) were chosen in order to demonstrate their green potential. 
After the theoretical documentation and considering the results of the calculations, short conclusions have been drawn, highlighting the fact that when acting in a mature, informed and responsible manner, solutions can be found, adapted and applied.

The importance of this paper lies in the topical character of the research and in providing a solution to one of the most important challenges worldwide.

The research was based on several research platforms and calculators of the carbon footprint.

\section{Materials and Methods}

\subsection{Theoretical Approaches of the Carbon Footprint Concept in the Context of Globalization}

The world today is operating within an ever more tightly interconnected economic system made up of scenarios, models and sub-systems, widely known as globalization. Although humanity's aim is to eliminate the disparities among the countries worldwide, the development trend is unequal, with each country, be they Asian, American or European, using different strategies to achieve prosperity [7]. The current dynamism represents a challenge for the decision makers at the government level to find a balance between the economic objectives and the way to reach them while avoiding the destroying of the environment.

The present research is based on a bibliometric analysis using the content on the Scopus platform, covering the time interval between 1962 and now. The reference year 1962 was chosen because this was the moment when the subject of air pollution and sustainability began to attract the attention of the general public, also including the years that preceded the 1970 oil crisis. The year of 1962 was also the year when the book "Silent Spring" was written [8], as a first attempt to explain sustainable development through green facades.

The present research study took 452 papers into consideration. The bibliometric analysis, which was made with the help of the VosViewer software version 1.6.7. (Leiden University's Centre for Science and Technology Studies (CWTS), Leiden, Netherlands), shows that universities all over the world are researching this field, with the academic environment of the United States of America registering a total of 132 published articles and Kyung Hee University of China nine published articles, while in Romania there is only one article published on this topic, by Gheorghe Asachi University in Iași. Considering that in this Romanian study there is no reference to the applicability of the activities related to sustainability in a model of economic efficiency, the present article aims to make a specific contribution in this field.

With the beginning of this millennium, the amount of raw materials and of intermediary or final products of various complexity levels (most of them being at the high end of this scale) have increased their presence in the soil, water and air [9]. This is an alarming aspect, urging for better waste management.

The current world context is characterized by an unprecedented dynamism, which calls for monitoring, so that the environment indicators would reach an optimal level. Over the last few decades, the institutional changes and the evolution of the social and political relationships alongside the environmental issues have become more and more interconnected [10].)

The approach towards a global economy from the consumption viewpoint, supported by the accelerated pace of technological advances, has led to the degradation of nature, as indicated by several alarming situations that can degenerate into catastrophes within a short time span.

Specialized literature signals frequent, subtle issues, which draw attention to pollution, such as the outsourcing of production by the technologically advanced, financially powerful countries to so-called emerging states that are almost industrialized, thus creating the illusion of a win-win system, where all the parties involved have to gain. This point of view takes into consideration only the material aspect, while the long- and medium-term costs associated with the pollution of the environment for obtaining a global manufacturing system are often neglected [11]. 
The current geographical constraints generate difficulties in managing the environment, a fact that was also noticed by Waters in his 1995 impactful publication [12].

The current climate variations unveil the effects of perpetual pollution, and this change in the seasons does not come solely with psychological discomfort, but also with warnings about the ever-higher incidence of diseases and the existence of certain types of viruses, which are more aggressive and more resistant than ever before. One should also note the existence of both political and social voices militating for optimizing the indicators and ensuring ecological sustainability.

The answer given by the contemporary business world to the driving forces of globalization currently depends on the influence of environmental pollution. The effective management of a sustainable economy in an unpredictable context requires that the global policies should be restructured, so that the responsibility to ensure sustainability is no longer just a research concept, but a task attributed to continents, countries, organizations and individuals. Thus, the business schools and economic research centers are made accountable, since their approach is threefold, involving at the same time the social, economic and ecological components, coupled with monitoring the global attitudes in these three areas [13].

Such statements related to threefold decisions (from the point of view of the social environment involved) are to be found in specialized literature since 1992. This observation was made by William Rees, who draws attention to how the approaches have changed over the past few years. These changes are remarkable, because nowadays the political approach is threefold, including the economic environment, the natural environment and the social environment [14]. Due to the fact that two of the variables (economic and social) have undergone changes induced by the change in world consumption, with the help of globalization, the third variable has been implicitly affected as well, requiring to be prioritized on the list of issues humanity is currently being confronted with and that need to be solved.

The pressure of the race against time to reduce pollution and to obtain close to optimum levels of the indicators that reflect these concepts has currently led to intense debates related to individual instinct versus ethics as far as consumption and capitalism are concerned, since the ratio between the available resources and the world population, which is on an exponential increase, is deeply disproportionate. In its turn, this creates economic and health-related issues in a world where the accelerated pace of innovation does not seem to suffice.

The specialized literature describes globalization and sustainability as two concepts that require the attention of decision makers, since the economic and technological exponential growth has reached a critical point in destroying the environment [15].

The carbon footprint is an innovative concept popularized in Europe in the early 2000s, which describes the assessment of a limited life or production cycle. The scientific world unanimously accepts it as an indicator referring to the monitoring and interpretation of a segment of the greenhouse gases, namely the high concentration of carbon, which is aggressive to the environment [16]. The common denominator for measuring and calculating it was proposed at the international level by The United Nations Environment Programme - Sustainable Building and Climate Initiative (UNEP-SBCI), which further proposed the Common Carbon Metric (CCM) [17].

A notable document and international conference in the field is the Kyoto Protocol, which was negotiated in 1997. In parallel, there was an impressive civic mobilization, when numerous companies and individuals voluntarily committed themselves to reducing and compensating their own greenhouse emissions. This historical event focused on the flexible economic mechanisms meant to help maintain the optimal levels of the parameters indicating the emission of greenhouse gases into the atmosphere [18].

The voluntary compensation market is dynamic and experiencing an exponential growth, and is worth approximately 10 million tons of carbon dioxide resulting from the already traded carbon offset projects run so far. The voluntary financial compensation projects, which do not fall under the provisions of the Kyoto Protocol, are often characterized as small, diverse and innovative, the last two attributes representing a potential source of wealth. However, the lack of clarity, the confusing and 
poorly defined stipulations and traceability of products may allow projects of doubtful quality to reach the current market [19].

More than 20 years ago, Jeffrey Amthor maintained the fact that this accumulation of climate variations and changes is due to the increase in the carbon dioxide emissions $\left(\mathrm{CO}_{2}\right)$ into the atmosphere, but that it was not easy to find direct evidence in support of this theory [20].

In the literature we can find the "ark syndrome" concept, which highlights the issue of the continuous economic growth and the elimination of its expansionist borders [21], due to the fact that this growth must be supported by resources and until the time an unlimited source is tapped, this desire remains a utopia.

A traditional approach considers only two types of resources, namely: fossil fuel-generated energy and the accumulation of raw materials. By nature, these are exhaustible, namely the more you use them, the faster they will be consumed. On the other hand, the technological advances have brought about the information society, which is currently advancing towards the knowledge society. The academic voices are thus raising hopes at the macroeconomic level by means of academic research, which represents a catalyst in implementing the new technology at the society, organization and individual level [22].

The access of humans to new energy sources has been a concern for some time. As the fossil fuel reserve is more and more affected and more and more greenhouse gases are produced, using green, technologized and easy to apply energy is the solution that humans need on a large scale in order to access sustainable energy resources [23].

There are frequent discussions in the academic world about an imminent economic collapse. The reason for this imminence is represented by the need for a better management of the environmental factors. If this need is not met, there will be an ecological collapse, because both the much-desired economic growth and the speedy technological development are taking place in an unstable biosphere with numerous "sensitive points".

At the moment, sustainability is one of the great world challenges, and air pollution, namely keeping the carbon footprint within optimal limits, is inviting the political decision makers to an intense, wide and prompt reflective process with a view to conserving biodiversity.

The transition to this new paradigm is pushing the responsibility downwards on the social pyramid. At the moment, the pollution issue is no longer an abstract concept for the small businesses or for the individual, since every economic unit is fully and directly accountable for the carbon footprint level [24].

During the past decades, studying the carbon footprint was considered essential. In 1992, at British Columbia University, Professor William Rees introduced this concept for the first time, defining its content and limitations. He stated that the level of the world carbon footprint is by far higher than the regeneration power of the planet, considering the estimated pace and consumption frequency at that moment in time, which are also valid today [14]. Therefore, many academics studying this topic or sustainability-related topics recommend that the analysis of the carbon footprint indicators and implicitly of air pollution should be correlated with the consumption behavior, which is now characterized by volumes, versatility and unpredictability. Therefore, continuing this consumerist style supports the exploitation of both the economic and the natural environment.

Roberts maintained that, to a varying degree, pollution is determined by the behavior of individuals, who, while performing daily or tourist activities, are directly involved in keeping an optimal level of the aesthetic, sanitary, hygienic and recreational functions of the environment [25]. Later on, academic research evolved, coming to underline the fact that the generated carbon footprint was higher at the community level as compared to the one produced by transnational companies.

The concept studied in this paper was created with a clear purpose, namely of monitoring and calculating an essential aspect of durability: the extent to which the productive ecosystems of this planet can satisfy the new types of need that appeared over the past 50 years in a balanced way, proportional to the power of regeneration of the resources [26]. 
The term durability has been present in the vocabulary since antiquity, but its semantic valences are different now, when, at the start of the millennium, we are talking about durable development, which is a new concept. It describes the evolution of the human civilization in agreement with the optimal parameters of the ecosystem, avoiding damaging their level, with the intention of passing on a healthy environment to the next generations, suitable for their development, which is a challenging matter given the demographic boom [27].

In Romania, in 2008, the specialized literature mentioned the fact that the carbon footprint concept relies on a calculation of the planet's regeneration capacity, at a time when humanity is set only on using the available resources and not on conserving or using them in a sustainable manner [28].

Nowadays, sustainability is no longer understood as made up of strictly punctual issues, but as an overall concept covering the whole system of life.

\subsection{Theoretical Approaches of the Carbon Footprint of Buildings}

The carbon footprint concept allows researchers to study the consumption patterns from a new perspective, in order to obtain a more realistic image of a country's ability to meet the people's needs and its capacity to regenerate and keep producing such resources over a determined period of time (most researchers use the 1 year standard).

The increased flexibility of the offer available on the market is due to the redundant commercial channels, which offer the final client a high degree of freedom in terms of options, which is also extrapolated in terms of energy consumption [29].

It is worth mentioning that at the moment all the European Union Member States are being confronted with more or less significant ecological deficits. By comparison, Romania is still enjoying an optimistic value, lower than the average of other EU Member States, of approximately 2.4 global hectares (gha) per capita, although the consumption behavior patterns are indicating a worrying upwards trend [28].

The main variables that influence the carbon footprint level are related to the means of transport an individual or organization frequently opt for, the eating pattern adopted, the non-food items consumed and, last but not least, the household energy consumption [30].

The household could be described as a space where activities are performed, since it is a generic term for the building where the companies perform their daily activities. The big carbon footprint generators are the public buildings, such as city halls, schools, hospitals, boarding houses, etc.

Worldwide, buildings, and more specifically their energy consumption, account for $40 \%$ of the volume of carbon released into the atmosphere [31].

There is a stringent need for the decision makers at the international community level, as well as at the national level, to become involved, since at the moment there is no legal framework with clear stipulations about how to deal with the carbon pollution produced by non-industrial buildings. At present, such buildings are regulated by two relatively recently amended directives, one referring to ecological design and the other related to the buildings' ecological performance [32].

It is essential that a debate should be organized on the topic of energy efficiency, because Romania's fossil resources are plummeting, which is making the country dependent on imports. This dependency has been dramatically increasing over the past years and it is prompting the media to produce scenarios referring to an "economic colonization" of this country [33].

The directive on the ecological performance of buildings introduces the concept of a low energy house or building, this notion being defined by an energetic consumption close to zero, thus highlighting the importance of using green energy, not only at the research level, but also on a daily basis. A low-energy building is the one inside of which we can be comfortable irrespective of the season without using a conventional source of energy, the focus being on climate control [34].

This legal provision is also coming with a deadline (31 December 2020) by which the Member States must comply with a high-energy performance level. This way, the issue reaches the economic 
world, the companies being forced to find a balance between the costs and the environmental benefits generated, because these must be assessed in the long run, throughout the life span of a building [35].

Although the biggest impediment faced by the economic agents in this respect is of a financial nature, one should not neglect the opportunities offered by this framework. It makes it possible to identify the sensitive aspects within the living spaces, with a view to identifying and controlling the risks, as well as to obtain a lower, limited and controllable consumption of the resources, generating savings in the long term. Likewise, in terms of local and regional public health budgets, the costs allotted for treating lung, cardiac and digestive diseases will go down over time as a consequence of lower air pollution levels.

Another opportunity that is better used by corporations is that of consolidating the image of the institution or locality, since the marketing department can use this process in order to consolidate an environmentally friendly brand, in response to the market demand for ecological performance.

The unprecedented economic progress seen by humanity over the past century has fostered consumption in its various forms, even at the energy level. At the moment, redirecting the consumption is a matter of concern, given the fact that the demographic boom is not likely to lead to its decrease [36].

In Romania, the nature of the habitat in rural areas imposes specific strategies, because there are still isolated houses, the dispersion of buildings being quite high. Due to the demographic characteristics of rural areas, the conventional, low voltage electricity system can be avoided by means of individual installations using green energy from renewable sources. The economic scenarios produced in this respect are positive from the viewpoint of the costs involved, but only over a longer period of time of around 20-30 years. However, creating such a network implies a big investment from the local budget, since the related costs are substantial [37].

Thus, the discussion in the academic environment starts with the basic heat transfer and heat absorbing construction elements (green energy proposes the ones that absorb the solar heat and light) and continues with designing the tools that will produce the desired effects [38].

Even within this niche of the energy domain there is a sub-niche that proposes the use of solar energy by means of solar loops or heat pumps that are connected only to the source element of solar heat [39]. These studies and proposals are fostering the further development of specific equipment with a warranty that would seem utopian in a consumerist age, namely for life.

The political reforms initiated after 1989 had the purpose to dismantle monopolies and to decentralize the economy by privatizing its main units, thus creating the framework for the development of a necessary niche [40] for renewable energy, which, with social and economic support, should grow out of its current "niche energy" status during the following years.

Although the renewable energy actors have earned their right to compete on the market, this right cannot be properly turned to account in the absence of government tools, which are properly supported and popularized.

The development strategy of Romania for 2016-2035 addresses, inter alia, the bioenergy sub-sector (biogas, biomass, biofuel) and biotechnologies of environment [41].

Romania was a pioneer within the European Union, being the first Eastern European signatory of the Renewable Energy and Energy Efficiency Partnership. The calculations of the Ministry of the Environment describe the renewable energy production capacity as follows: $65 \%$ of it would result from biomass, $4 \%$ from the sun and $1 \%$ would be voltaic and geothermal, although the geothermal source is a prolific one [42]. However, another impediment for the real economy lies in the fact that the workforce has emigrated during the past 30 years and the offer of skilled staff for installing, mounting and maintaining such equipment is fairly low, and consequently, according to the economic laws, expensive.

During the past three decades, significant steps have been made to create new methodologies, tools and equipment, which would systematically support the environmental strategies with a view to putting the green energy innovations into practice. Nowadays we have a better understanding of how human actions are impacting the environment [43]. Even if each individual on the planet is faced with 
the carbon footprint challenge, the ensuing responsibilities are not clearly defined, at least from the quantitative viewpoint. It is most likely that the future will bring these clarifications, once the public expectations increase as a consequence of the severe climate change.

\section{Applying the Method of Reducing the Carbon Footprint in the Case of the Bucharest University of Economic Studies in an Economically Efficient Manner}

The prospects for reducing the carbon footprint in the public sector should not be considered only as involving extensive initial changes, since the concern for the environment can also be shown by means of low cost changes that may bring generous image benefits, as well as environmental advantages. An environmental cost-benefit analysis is difficult to perform because of the limitations due to the lack of data in this field. It is worth mentioning that a ton of carbon dioxide currently costs 13.67 euros.

In order to reduce the carbon footprint generated by the Bucharest University of Economic Studies, the approximate current situation of two bodies in the complex of the institution was taken into account. Reducing the carbon footprint of the BUES community, which consists of 23,000 people, would generate a special impact.

The first implementation proposal, in response to the need for the buildings with a public purpose to become more eco-friendly, involves placing a vertical garden on one of the facades of BUES, which would generate marketing opportunities and other advantages.

The second proposal is based on the desire of the students from the NGO of the Faculty of AgriFood and Environmental Economics to trigger a change of lifestyle and lay the foundations of some activities meant to set a long-term example for the Bucharest student community involved in ecology.

\section{The Current State of the Buildings}

The researched area is located in the urban space of the municipality of Bucharest. The dimensions of the researched buildings within the Bucharest University of Economic Studies are the following: Building A: 5612 square meters and Building C: 715 square meters (1500 square meters with yard).

Both buildings have nine levels, seven on aboveground and two underground, each level summing up to 623.56 square meters. The structure system is a mixed one (concrete, steel, wood, etc.). Moreover, in the surrounding area there are fruit trees (seven apple trees, seven cherry plum trees, two plum trees, two cherry trees, one mulberry tree and shrubs).

No additional access routes are proposed, as the location benefits from several entrances and exits, being situated in the immediate vicinity of an important intersection.

In case of an earthquake, structural degradation may occur, but it would not risk destabilizing the construction. Currently, the buildings are connected to all the utilities systems that use conventional energy, all being functional. The climatic factors in the area where the buildings are located do not represent an investment risk.

With the help of Romania Green Building Council and Build Carbon Neutral, the footprints of the Bucharest University of Economic Studies Buildings A and C were estimated, using the software made available online (Figures 1 and 2 [44]).

This software estimates the carbon that is embodied in the construction, and it is used as a tool in the management of the carbon footprint reduction. It takes into consideration the site, the landscape and the eco installation disturbance, and it requires basic information regarding the technical aspects of the building irrespective of whether it is a public one or a household. The results it provides refer to the carbon footprint of a building as a whole and they are $\pm 25 \%$ accurate. In our specific situation, it is important to mention that the carbon footprint of the underground levels is embodied in the stories above the ground. One argument in favor of using such software is that, for example, $13 \%$ of the global carbon footprint is generated by transportation, while the carbon footprint of buildings accounts for $19 \%$ [17]. In this way, a holistic approach can be obtained when assessing the pollution generated by any type of building, be it public or private (household). 
Construction Carbon Calculator Results

Approximate net embodied $\mathrm{CO} 2$ for this project is 165 metric tons.

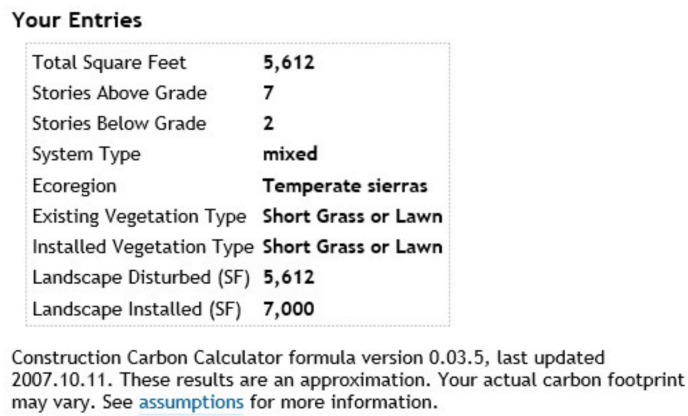

Figure 1. Calculation of the carbon footprint of Building A, the Bucharest University of Economic Studies. Source: www.buildcarbonneutral.com [44].

\title{
Construction Carbon Calculator Results
}

Approximate net embodied $\mathrm{CO} 2$ for this project is

\section{6 metric tons.}

\author{
Your Entries \\ Total Square Feet $\quad \mathbf{7 1 5}$ \\ Stories Above Grade $\quad 2$ \\ Stories Below Grade $\quad \mathbf{7}$ \\ System Type mixed \\ Ecoregion Great plains \\ Existing Vegetation Type Previously Developed \\ Installed Vegetation Type Short Grass or Lawn \\ Landscape Disturbed (SF) 1,000 \\ Landscape Installed (SF) $\mathbf{7 1 5}$ \\ Construction Carbon Calculator formula version 0.03.5, last updated \\ 2007.10.11. These results are an approximation. Your actual carbon footprint \\ may vary. See assumptions for more information.
}

Figure 2. Calculation of the carbon footprint of Building C, the Bucharest University of Economic

Studies. Source: www.buildcarbonneutral.com [44].

The value calculated by the software is a rough one, vitiated by the limitations of the research, but it provides the essentials regarding the worryingly high values of the carbon pollution, which slowly affects the community of 23,000 people and more.

Even if at first sight the value for Building $C$ seems optimistic, one should take into account both the proportionality with the built surface and the fact that this construction benefits from a large garden of 1500 square meters.

From a comparative perspective, the optimal annual value of the carbon footprint is 2 tons per year per person. The average footprint of a European person is 10 tons per year.

In an optimistic scenario, the national governments and European officials rely on reducing the use of conventional energy and increasing the use of clean, green energy by 2050.

However, it should be mentioned that although efforts are being made to implement measures that will lead to a rise in the use of green energy, producing and/or using it is still creating pollution (Figure $3[45]$ ). 


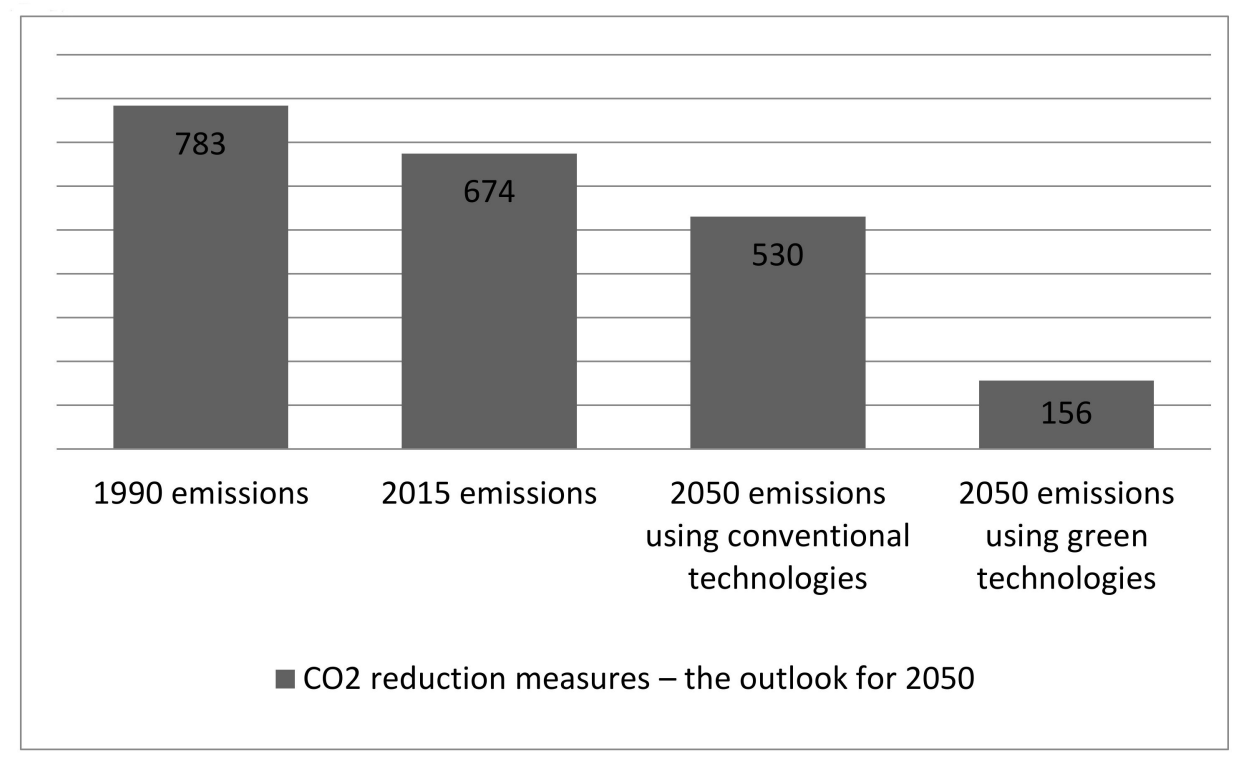

Figure 3. CO2 reduction measures—the outlook for 2050. Source: CEMBUREAU [45].

In order to mitigate the consequences produced by the high values of the indicator analyzed in this paper, the construction of a vertical garden of $100 \mathrm{~m}^{2}$ was considered, followed by the setting up of an urban garden on the sixth floor of Building A, supported by volunteering and public or private funding. Additionally, its maintenance costs could also be covered by attracting public or private funds.

\section{Results}

The two proposed constructions (i.e., vertical garden and urban garden) are part of a relatively new eco-landscape concept. According to statistics, over $80 \%$ of this kind of buildings were created after 2007 , and over $93 \%$ of the urban gardens were built after 2009. They can be built indoors as well as outdoors.

This concept is relatively new because although it was patented in the US in 1938, in Europe it has only started to become popular in the 1980s. The largest project of this kind, consisting of a wall covered with vegetation with an area of approximately 2700 square meters, can be found in Mexico.

\section{The construction of a vertical garden}

When it comes to urban gardens, it is essential to consider that they are of three types:

- $\quad$ Green facade;

- $\quad$ Living wall;

- $\quad$ Support wall.

A green facade is a plant system that often requires a special microclimate regime. In the case of high buildings, the plants are planted in the ground at the base of the construction, or in strategically placed pots, being expected to meet their objective of shading and preserving the temperature after several seasons.

Living walls consist of panels with plants that were previously mounted on them, their advantage as compared with a green facade being density. The preferred plants for this type of installation are the perennial or aromatic ones. Because the panels are modular, they are highly flexible and adaptable to the climatic conditions, resisting both in arid areas and in those with a high level of humidity.

Green support walls are the most elaborate construction, their purpose being to attenuate the slopes at an angle greater than 45 degrees but less than 88 degrees. At the base there are tiles made of different materials, previously filled with the type of soil that is adequate to the plants used. 
The aesthetic role is fulfilled only after the plants have reached maturity and the enveloped surface is perfectly covered by plants.

The vegetal envelope protects the exterior of the building and, due to the permeability of the materials used, the oxygen level is ensured to those who perform their activity inside the building. This is achieved through the processes of resuspension of dust and allergens in its composition (a process that prevents the emergence of allergies) and of absorption through the roots.

For the purpose of the present research, out of the three abovementioned options, a vertical garden (facade type) was opted for, due to the fact that it has lower costs than the other two, since its maintenance (near zero) and complexity levels proposed in the project are minimal.

The advantages of a vertical garden:

- One square meter covered with plants holds up to $130 \mathrm{~g}$ of dust and can produce the amount of oxygen needed by an individual over a year;

- The effect of the "heat island" present in urban agglomerations during the summer season is diminished until it becomes blurred;

- A medium-sized vertical garden (60 square meters) captures 40 tons of carbon in a year, thus being sufficient for six people, even under the current conditions for reducing the imprint associated with this chemical element;

- From a real-estate point of view, the value of the building increases because of the higher environmental benefits;

- The mental state of the employees in such a building is modified in a positive manner, due to its aesthetic impact, thus creating the premises for an increase in their efficiency;

- Its installation requires a short time;

- Not only is the air pollution reduced, but also the noise (up to 10 decibels);

- If species of lichens are used, they are not a suitable environment for the development of microorganisms and do not require maintenance efforts.

The construction of an urban garden

When it comes to the green space per capita, Bucharest ranks very low among the other European capitals. At the European Union level it has been decided that the optimal green space area per capita should be 26 square meters. At the national level, the data from the National Institute for Statistics indicate that a Romanian benefits from 21.4 square meters of green space. On the other hand, the World Health Organization considers the optimum to be of 50 squares meters per capita.

Taking all this into account, the prospect of developing an urban garden at a height, like in our case, on a large terrace of about $100 \mathrm{~m}^{2}$, represents the way to adapt to modern times and the desire to evolve in an era of ruthless consumption and speed.

By involving public and private entities as well as volunteers in the project, its implementation can be done with minimal expenses, in such a manner that in the medium and long term it does not only improve the environment but also generates profit.

Plant seedlings (cauliflower, tomatoes, cucumbers, red beets) and aromatic plants will be grown. They can generate added value through processing (pickles) and can be used in the BUES canteens, where most of the community of about 23,000 people eat five days a week.

Additionally, the scraps obtained from the canteen can be used as compost, thus respecting a complete cycle of recycling and reuse. Water for drip irrigation will be collected from rainwater, and it will be directed to the garden with the help of the gravitational force.

The maintenance of the seedlings will be done in turns by groups of 5-10 volunteer students who are members of the ASEAM (Students' Association-AgriFood and Environmental Economics) NGO. The volunteer groups will provide daily care for $2 \mathrm{~h}$, except during the summer when the periodicity is not as necessary. They will be regularly assisted by agriculture and horticulture teachers, engineers or other experts in this field, who will supervise their activity. The accounting, marketing, and advertising 
costs will be covered or even offered free of charge by the ASEAM alumni community (since these are their areas of specialization).

\section{Discussion}

The two projects presented above can be implemented in any academic community and in time they will both have a genuine environmental impact by generating a lower amount of carbon.

Such projects can also lead to improved sustainability thanks to the high level of productivity resulting from the good communication among all the individuals involved in volunteering projects in a micro academic environment.

The project costs are relatively low and they could be covered from either private or public funding.

In our case, the costs for building the vertical garden are of approximately 2760 euros, while those for the urban garden amount to about 9000 euros (to be spent over a three-year implementation period), as can be seen in Tables 1 and 2 below:

Table 1. The costs of building a 100 square meter green facade.

\begin{tabular}{|c|c|c|c|c|}
\hline No. & Plant Name and Technical Materials & $\begin{array}{l}\text { Unit Price } \\
\text { EUR }\end{array}$ & $\begin{array}{l}\text { Quantity } \\
\text { (Items) }\end{array}$ & Total EUR \\
\hline 1. & $\begin{array}{l}\text { Capsule with metric type thread/steel } \\
\text { eye screw- } 8 \times 43 / 12 \times 215 \mathrm{~mm}\end{array}$ & 1.77 & 70 & 123.95 \\
\hline 2. & Stainless steel spinodal cable, AISI 316 & 4.67 & 325 (meters) & 1520.05 \\
\hline 3. & Steel tensioner for tensioning & 2.08 & 310 & 644.82 \\
\hline 4. & Clamps for connecting cables & 2.5 & 40 & 100 \\
\hline 5. & Plants-lichens & 72.5 & 1 & 72.5 \\
\hline \multirow{3}{*}{6.} & Manpower costs-assemblage & $\begin{array}{l}10 \% \text { of the price of } \\
\text { materials }\end{array}$ & 1 & 246.23 \\
\hline & Planting in the soil & 10.41 & 1 & 10.41 \\
\hline & Plants hanging & 41.66 & 1 & 41.66 \\
\hline & Price per facade square meter & & & 27.53 \\
\hline 7. & TOTAL (EUR) & & & 2760.66 \\
\hline
\end{tabular}

Table 2. The costs of building a 100 square meter urban garden.

\begin{tabular}{|c|c|c|c|c|}
\hline Budget Category & Unit & Unit Price (EUR) & Quantity (Items) & Total Cost (EUR) \\
\hline \multicolumn{5}{|c|}{ 1. Human Resources (Project Team, Staff from the Financial Department Involved in Reporting, Collaborators) } \\
\hline $\begin{array}{l}\text { Coordinator GrădinASEAM (Students' } \\
\text { Association-AgriFood and Environmental } \\
\text { Economics)—Roxana Chiocaru }\end{array}$ & month & & & 0 \\
\hline ASEAM Volunteers & month & & & 0 \\
\hline Cat & abtotal & & & 0 \\
\hline \multicolumn{5}{|c|}{ 2. Direct Project Costs (Services, Materials, Equipment, etc.) } \\
\hline \multicolumn{4}{|c|}{ 2.1 Design Services, Implementation, Maintenance, etc. } & 395.83 \\
\hline Backhoe Rental & day & 166.66 & 2 & 1595.2 \\
\hline Backhoe Handling & day & 31.25 & 2 & 62.5 \\
\hline
\end{tabular}


Table 2. Cont.

\begin{tabular}{|c|c|c|c|c|}
\hline Budget Category & Unit & Unit Price (EUR) & Quantity (Items) & Total Cost (EUR) \\
\hline \multicolumn{4}{|c|}{ 2.2 Materials/Equipment } & 6369.47 \\
\hline Vegetal Soil & $\mathrm{m} 3$ & 20.83 & 30 & 625 \\
\hline Compost & $\mathrm{m} 3$ & 104.16 & 1.3 & 135.41 \\
\hline Aromatic Plants & piece & 3.12 & 72.3 & 225.93 \\
\hline Seed Varieties & sachet & 2.08 & 20 & 41.66 \\
\hline Cauliflower Seedlings & piece & 4.16 & 1.5 & 6.25 \\
\hline Cucumber Seedlings & piece & 8.33 & 1 & 8.33 \\
\hline Red Sugar Beet Seedlings & piece & 4.16 & 1.2 & 5 \\
\hline Red Seedlings & piece & 20.83 & 1 & 20.83 \\
\hline Mulch Pedestrian Alleys & $\mathrm{m} 3$ & 52.08 & 6 & 312.5 \\
\hline Fruit Trees and Shrubs & piece & 2.08 & 50 & 104.16 \\
\hline $\begin{array}{c}4 \times 1 \mathrm{~m} \text { High Layer Materials (Timber, Hollow Screw, } \\
\text { Corner etc.) }\end{array}$ & piece & 72.91 & 25 & 1822.91 \\
\hline $\begin{array}{l}\text { Irrigation System (Programmer, ppr } 32 \text { Pipe, ppr } 40 \text { Pipe, } \\
\text { Flexible Tube, Drip Tube, Sockets, Consumables) }\end{array}$ & system & 1145.83 & 1 & 1145.83 \\
\hline $\begin{array}{c}\text { Hand Tools (Shovel, Spade, Pickaxe, Shovel, Fork, Rake, } \\
\text { Hand Scissors, Power Scissors, Saw) }\end{array}$ & piece & 13.54 & 35 & 273.95 \\
\hline Soffits & piece & 2.08 & 20 & 41.76 \\
\hline Wheelbarrow & piece & 38.54 & 2 & 77.08 \\
\hline Solar & piece & 833.33 & 1 & 833.33 \\
\hline Materials Needed for the Composting Area & piece & 72.91 & 1 & 72.91 \\
\hline Storage for Materials & piece & 416.66 & 1 & 416.66 \\
\hline \multicolumn{4}{|c|}{2.3 Transportation } & 469.79 \\
\hline Material Transportation & piece & 62.5 & 6 & 375 \\
\hline Fuel & 1 & 15.62 & 6.5 & 94.79 \\
\hline \multicolumn{4}{|c|}{ 2.4 Organization of Events (Services and Materials) } & 104.16 \\
\hline Event Organizing Materials (Tea, Water, Food etc.) & piece & 5.20 & 20 & 104.16 \\
\hline $\begin{array}{l}\text { Promotion and Communication Services (Activity } \\
\text { provided free of charge by ASEAM volunteers) }\end{array}$ & piece & 1 & 0 & 0 \\
\hline \multicolumn{4}{|c|}{ 2.5 Promotion and Communication of Projects (Services and Materials) } & 125 \\
\hline Promotional Materials (Facebook Ads) & piece & 6.25 & 20 & 125 \\
\hline $\begin{array}{l}\text { Online Promotion (via the social networks groups of the } \\
\text { universities in Bucharest and others in the country) }\end{array}$ & piece & 1 & 0 & 0 \\
\hline \multicolumn{4}{|c|}{ 2.6 Graphic and Design Services (Services and Materials) } & 666.66 \\
\hline $\begin{array}{l}\text { Flyers, Posters, Banners, Explanatory Panels, Garden } \\
\text { Signage-Design and Execution }\end{array}$ & piece & 416.66 & 1 & 416.66 \\
\hline $\begin{array}{l}\text { Flyers Distribution in BUES Campus-ASEAM } \\
\text { Volunteers }\end{array}$ & piece & 1 & 0 & 0 \\
\hline Photo-Video Documentation & piece & 20.83 & 12 & 250 \\
\hline Category subtotal & & & & 8130.93 \\
\hline \multicolumn{5}{|c|}{ 3. Administrative Costs-Maximum $10 \%$ of the Project Budget } \\
\hline $\begin{array}{l}\text { Protocol (water, tea, fruit, vegetables, food, etc., other } \\
\text { required products during organized events, glasses) }\end{array}$ & piece & 4.16 & 12 & 50 \\
\hline Office supplies & piece & 41.66 & 1 & 41.66 \\
\hline Projector & piece & 243.02 & 1 & 243.02 \\
\hline Photo-video camera & piece & 416.54 & 1 & 416.54 \\
\hline Category subtotal & & & & 751.22 \\
\hline 4. Other expenses & & & & 0 \\
\hline \multicolumn{4}{|c|}{ TOTAL (EUR) } & 8882.16 \\
\hline
\end{tabular}

Source: personal calculation by example budget form "Creștem Grădinescu" [46]. 
For this type of project, the financing can be external, both from the public and the private sector, as follows:

\section{A. The Environmental Fund}

According to Romanian legislation (Law no. 105/2006), projects that provide for the reduction of noise pollution in the urban environment, the management and use of clean technologies (thus creating an environment conducive to the conservation of biodiversity), reducing the impact of pollution on air, water and soil and reducing greenhouse gases (i.e., including carbon released into the atmosphere) are eligible for funding of up to 100,000 euros.

\section{B. Private funds}

From the private sector, the support for such projects includes the financing through the project entitled “Creștem Grădinescu—finanţare pentru grădini şi ferme urbane" (maximum 130,000 euros).

The projects proposed in this paper meet the budget requirements set by both entities. However, the second financing option was selected because besides the financial support, the financing project team also provides coordination and assistance throughout the project (Table 2 [46]).

Civil involvement in these types of projects is essential, because the power of the example of some volunteer activities with an ecological character specific to a healthy lifestyle with a progressive perspective is much higher than that of motivational speeches.

Implementing such a project within the Bucharest University of Economic Studies is meant to support the practical aspect of education and to establish information and awareness-raising campaigns that combine practice with theory. Additionally, collaboration between the educational actors is also desired, both inside and outside the university. Access to local products will be greatly facilitated in this context, as BUES canteens can reduce their expenses in the medium and long term, and the community of this institution will enjoy local products.

The social and economic impact will consist of encouraging new segments of the agriculture and environment sectors to apply contemporary innovations, relying on the feeling of community.

Debt and fines (if any), interest or penalties, costs of leasing, renting, or awarding cash prizes are included in the ineligible expenses area.

For eligibility it is necessary to participate in teams of at least three people, thus encouraging collaboration rather than competitiveness.

The implementation of this project is intended to bring about a change in the perception of living in a European capital, often considered as crowded and suffocating. The increase of green spaces, of urban gardens and farms, psychologically supports the human connection with nature, minimizing the effect of "robotic life", establishing a new social architecture and ensuring that the environment is also included.

\section{Conclusions}

Reducing the carbon footprint in order to meet the optimal values of the sustainability standards can be done through small actions that are also economically effective and are not intended exclusively for a specific type of building. Implementing concrete actions in a university campus can be a new way of approaching the world today and it should become part of the students' education for achieving higher living standards and sustainability.

Opting for urban gardens or for vegetable envelopment brings many benefits to humanity, but it also restores the human-nature balance. The aspect of birds abandoning the urban environment or their early death must also be taken into account. This phenomenon is caused by birds colliding with the multitude of buildings, as they do not have the ability to perceive transparent surfaces, therefore producing another imbalance in the biodiversity, which can be reconciled through solutions like the ones proposed in this paper. They allow the comfort of life in the city for both humans and animals. 
While a wall made of brick or covered with polystyrene (considered cancerous by researchers) favors the suspension of particles and microorganisms in the air, buildings enveloped in vegetation retain and recycle dust and carbon dioxide, thus giving an example of ecological regeneration.

On a large scale, if these proposals were adopted, not only would the aesthetics and the air in the building change, but also the perception of people about the workplace, the city and life, since nature induces a state of calm, relaxation and hope. On the other hand, a space dominated by concrete is perfect for generating anxiety.

Reorientation towards the traditional values, natural capital and local food leads to a healthy life. At the same time, this type of insulation offers an alternative recreational space through its texture and brightness.

Turning to renewable energy represents a step forward in the contemporary society, a step that ensures progress. The dispersal of the society and the individualization were the precursors of the Revolution of 1989, and the community spirit had to suffer. It can be saved by volunteering, especially as presented in this paper, which unites both the people in the academic community and those outside it. The Bucharest University of Economic Studies can again serve as an example for Romania from a perspective that shows thoughtfulness for the environment, students, teachers and life in general.

In conclusion, this paper has illustrated how easy it is to make a change with a minimal investment, provided there is dedication and interest. Our society needs to take action in this crucial moment when the resources and quality of life can still be saved. In the absence of a responsible attitude associated with this sensitive point in the history of society, the future generations will have to suffer since they will have no alternative option.

Author Contributions: Conceptualization, S.R.P., M.D., C.N. and R.C.; Data curation, S.R.P. and R.C.; Formal analysis, S.R.P., M.D., C.N., and R.C.; Investigation, S.R.P., C.N. and R.C.; Methodology, S.R.P., C.N. and M.D.; Project administration, S.R.P. and M.D.; Resources, S.R.P. and M.D.; Software, S.R.P. and R.C.; Supervision, S.R.P., C.N. and M.D.; Validation, S.R.P. and R.C.; Visualization, M.D. and R.C.; Writing-original draft, R.C.; Writing-review \& editing, S.R.P., M.D., C.N. and R.C. All authors have read and agreed to the published version of the manuscript.

Funding: This research received no external funding.

Conflicts of Interest: The authors declare no conflict of interest.

\section{References}

1. Mancini, M.S.; Galli, A.; Niccolucci, V.; Lin, D.; Bastianoni, S.; Wackernagel, M.; Marchettini, N. Ecological Footprint: Refining the carbon Footprint calculation. Ecol. Indic. 2016, 61, 390-403. [CrossRef]

2. Kohler, M. Green facades-A view back and some visions. Urban Ecosyst. 2008, 11, 236-423. [CrossRef]

3. Currie, B.A.; Bass, B. Estimates of air pollution mitigation with green plants and green roofs using the UFORE model. Urban Ecosyst. 2008, 11, 409-422. [CrossRef]

4. Alexandri, E.; Jones, P. Temperature decreases in a urban canyon due to green walls and green roofs in diverse climates. Build Environ. 2008, 43, 480-493. [CrossRef]

5. Chen, X.; Yang, H.; Lu, L. A comprehensive review on passive design approaches in green building ration tools. Renweable Sustain. Energy Rev. 2015, 50, 1425-1426. [CrossRef]

6. Francis, R.; Lorimer, J. Urban reconciliation ecology: The potential of living roofs and walls. J. Environ. Manag. 2011, 92, 1429-1437. [CrossRef]

7. Gribnicea, A. Globalizarea Economică Versus Dezvoltarea Durabilă; Nr. 1; Administrarea Publică: Republic of Moldova, 2019.

8. Carson, R. Silent Spring; Houghton Mifflin Company: United States, 1962.

9. Swart, R.J. Impacts of the Europe's Changing Climate-2008 Indicator-Based Assessment; European Environment Agency: Copenhagen, Denmark, 2008.

10. Dreher, A.; Gaston, N.; Martens, P. Introduction in Measuring Globalisation; Singer: New York, NY, USA, 2008.

11. Herrmann, I.T.; Hauschild, M.Z. Effects of Globalisation on Carbon Footprints of Products. CIRP Ann. 2009, 58, 13-16. [CrossRef]

12. Waters, M. Globalisation; Routledge: London, UK, 1995. 
13. Aggarwal, R. Developing a global mindset: Integrating demographics, sustainability, technology and globalization. J. Teach. Int. Bus. 2011, 22, 51-59. [CrossRef]

14. Rees, W. Ecological footprints and appropriated carrying capacity: What urban economics leaves out. Environ. Urban. 1992, 4, 121-130. [CrossRef]

15. Willy, B. A program for survival. Independent Commission on International Development Issues. [Auszug aus: North-South: A programme for survival]. Econ. Impact 1980, 4, 32.

16. Retail Forum for Sustenability. Measurement and reduction of carbon footprint of stores, Issue Paper 6. 2011. Available online: https://ec.europa.eu/environment/industry/retail/issue_papers.htm (accessed on 27 December 2019).

17. The United Nations Environment Programme-Sustainable Building and Climate Initiative (UNEP SBCI). Common Carbon Metric for Measuring Energy Use \& Reporting Greenhouse Gas Emissions from Building Operations. 2009. Available online: http://www.unep.org/sbci/pdfs/UNEPSBCICarbonMetric.pdf (accessed on 3 December 2019).

18. Radmilo, P.; Prodanovic, M.I.S.R. Economic Instruments for Reduction of Greenhouse gas Emission in Agriculture and Forestry. Econ. Agric. 2018, 65, 269-291.

19. Bellassen, V.; Leguet, B. The Emergence of Voluntary Carbon Offsetting; Mission Climate Research Report No. 11; Caisse des Depots: Paris, France, 2007.

20. Jeffrey, S.A. Terrestrial higher-plant response to increasing atmospheric $\left(\mathrm{CO}_{2}\right)$ in relation to the global carbon cycle. Glob. Chang. Biol. 1995, 1, 243-274.

21. Bridges, J.F. Stated preference: Methods in health care evalutation: An emerging methodological paradigm in health economics. Appl. Health Econ. Health Policy 2003, 2, 213-224. [PubMed]

22. Jacot, H.; Duval, G.; d'Auteurs, C. Le Travail dans la Societe de l'Information; Editions Liaisons: Paris, France, 2000.

23. ANCI. Agenția Națională Pentru Comunicații și Informatică, 2000, Strategia Națională de Dezvoltare Econimică pe Termen Mediu (2000-2004), Subcomisia 10—Comunicați și Tehnologia Informatiei; ANCI: Bucureșt, Romania, 2000.

24. Holden, N.M.; White, E.P.; Lange, M.C.; Oldfield, T.L. Review of sustenability of food systems and transitions using the Internet of Food. Sci. Food 2018, 2, 18.

25. Roberts, N. Schimbările majore ale mediului; Editura All Educational: București, Romania, 2002; pp. 3-19.

26. New Economics Foundation (NEF). Happy Planet Index Report; Karen, J., Wheatley, H., Saamah, A., Eds.; 2016.

27. Nicolae, G.-R. The Entropy Law And The Economic Process,; Harvard University Press: Cambridge, MA, USA, 1971.

28. Stanciu, M. Amprenta ecologică a României-o nouă perspectivă asupra dezvoltării. Calitatea Vieţii 2009, 20, 271-288.

29. Atanasoae, P. Modelarea sistemelor cu purtători multipli de energie în clădiri. Revista Româna Inginerie Civilă 2015, 6, 1 .

30. Martinez, Y. Análisis Económico y Ambiental de la Contaminación Por Nitratos en el Regadío. Ph.D. Thesis, University of Zaragoza, Zaragoza, Spain, 2002.

31. World Business Council for Sustainable Development 2009: Energy Efficiency in Buildings: Transforming the Market. Available online: www.wbcsd.org/includes/getTarget.asp?type=d\&id=MzQyMDU (accessed on 8 December 2019).

32. Directive 2010/31/EU of the European Parliament and of the Council of 19 May 2010 on the Energy Performance of Buildings. Available online: http://data.europa.eu/eli/dir/2010/31/oj (accessed on 11 November 2019).

33. Dobrescu, E.M. Energii Regenerabile, Academia Română, Institutul National de Cercetări Economice; Editura Sigma: București, Romania, 2009.

34. Daniel, E.s.F.W. Sustainable Design-Ecology, Architecture and Planning; John Wiley \& Sons: Hoboken, NJ, USA, 2007.

35. European Parliament, Council of the European Union. Directive 2009/125/EC of the European Parliament and of the Council of 21 October 2009 Establishing a Framework for the Setting of Ecodesign Requirements for Energy-Related Products. Available online: https://eur-lex.europa.eu/legal-content/EN/ALL/?uri=CELEX\% 3A32009L0125 (accessed on 6 November 2019).

36. Balan, M.; Verdeş, M.; Ciocan, V.; Verdeş, A. Studiu comparativ privind asigurarea energiei electrice din surse neconvenționale de energie pentru o clădire rezidențială. Revista Română Inginerie Civilă 2013, 4, 3. 
37. Mirea, A.; Plesca, V.; Dumitrescu, A.; Ardelean, V.; Plesca, M. Estimarea energiei electrice necesare si dimensionare unei instalații fotovoltaice autonome. Electrothenica Electrovoltaica Automatica 2012, 60, 2.

38. Preda, D. Problemele Dezvoltării și Implementării Unei Noi Tehnologii de Energie Regenerabiă; Conference: The National Conference on New and Renewable Energy Sources; Romanian Academy of Sciences: Bucharest, Romania, 2007; Volume VIII.

39. Iordache, F.s.R.M. Sistem de utilizare a surselor regenerabile pentru încălzirea unei clădiri rezidențiale. Metoda de evaluare a performașelor energetice. Analiza energetică, Revista Română Inginerie Civilă 2019, 10, 1.

40. UN Environment, Annual Report 2017. Available online: https://www.unenvironment.org/annualreport/ 2017/index.php (accessed on 12 December 2019).

41. Bran, Ş.D.; Chipurici, P.; Bran, M.; Vlaicu, A. Renewable Energy from Agricultural Waste. Revista Chimie 2018, 69, 1363-1366. [CrossRef]

42. Tureac, C.; Pripoaie, R.; Turtureanu, A.G.; Filip, A.C.; Ilie, A.M. Eficiența Economică, Socială și Ecologică a Energiei Eoliene. Ecoterra 2011, 26.

43. Bălan, C. Politica referitoare la amprenta de carbon a celor mai importanți zece detailiști la nivel global. Contribuție Dezvoltarea Durabilă 2017, 12, 27.

44. Build Carbon Neutral. Available online: www.buildcarbonneutral.com (accessed on 17 September 2019).

45. The European Cement Association (CEMBUREAU). Available online: https://lowcarboneconomy.cembureau. eu/wp-content/uploads/2018/12/CEMBUREAU-BUILDING-CARBON-NEUTRALITY-IN-EUROPE_final. pdf (accessed on 20 December 2019).

46. Creștem Grădinescu. Available online: https://gradinescu.ro/program-finantare/ (accessed on 31 October 2019).

(C) 2020 by the authors. Licensee MDPI, Basel, Switzerland. This article is an open access article distributed under the terms and conditions of the Creative Commons Attribution (CC BY) license (http://creativecommons.org/licenses/by/4.0/). 